\title{
HUBUNGAN ANTARA SELF CONCEPT DAN HOPE PADA PEMUDA DESA WAJAK, DAMPIT, SUMAWE MALANG JAWA TIMUR
}

\author{
Nangimatur Rofingah, \\ Muhammad Faishal Jamil, \\ Nurin Nazlah Maulida, \\ fpsi@uin-malang.ac.id \\ Fakultas Psikologi \\ Universitas Islam Negeri (UIN) Maulana Malik Ibrahim Malang
}

\begin{abstract}
Abstrak - Harapan dan penilaian akan diri merupakan dimensi utama self concept individu, setiap hari kita berperan sebagai penilaian tentang diri kita sendiri, menilai apakah kita bertentangan: 1) pengharapan bagi diri kita sendiri (saya dapat menjadi apa), 2) standar yang kita tetapkan bagi diri kita sendiri (saya seharusnya menjadi apa). Tujuan dari penelitian ini adalah untuk mengetahui adanya hubungan antara harapan dan konsep diri pada pemuda desa di kabupaten Malang. Analisis data menggunakan statistik parametric dan teknik korelasi product moment. Penelitian ini mengambil sampel 57 anak dari keseluruhan desa dikateorisasikan bahwa 28 anak berjenis kelamin laki-laki dan 29 anak berjenis kelamin wanita. Penelitian ini memberikan pemahaman bahwa lelaki dibandingkan dengan wanita cenderung gagal dalam pencapaian harapannya itu disebabkan karena perbedaan pengalaman (Muhammad dan mirra). Ditemukan bahwa $15,8 \%$ anak yang memiliki hope yang tinggi tetap memiliki self konsep yang rendah dan yang mendominasi kategori rendah adalah anak pria dengan jumlah kategorisasi rendah adalah 8 anak dan untuk anak yang berjenis kelamin wanita hanya 1 anak yang meskipun memiliki hope yang tinggi tetap memiliki self konsep yang rendah.
\end{abstract}

Kata Kunci: Harapan, Konsep Diri.

PSIKOISLAMIKA. Jurnal Psikologi Islam (JPI) copyright @ 2016 Pusat Penelitian dan Layanan Psikologi. Volume 13. Nomor 1, Tahun 2016

\section{PENDAHULUAN}

Data penduduk Indonesia pada tahun 2005 menunjukkan proporsi penduduk yang bertempat tinggal di pedesaan jika dibandingkan di perkotaan tidak lagi berbeda jauh, yakni 113,7 juta jiwa di pedesaan dan 106,2 juta jiwa di perkotaan. Namun, perbandingan tingkat kesejahteraan masyarakat dan tingkat pembangunan wilayah di antara keduanya menunjukkan kawasan pedesaan masih relatif tertinggal jika dibandingkan dengan perkotaan. Jumlah penduduk miskin di pedesaan pada tahun 2004 mencapai 24,6 juta jiwa, jauh lebih tinggi daripada di perkotaan, yaitu 11,5 juta jiwa. (BPS, 2005).
Maka dalam rangka memperbaiki kondisi krisis yang tengah dihadapi bangsa kita sehingga berimbas pada tersendatnya pembangunan di pedesaan. Keberadaan pemuda sebagai penggerak dan perubah keadaan sangat memainkan posisi yang strategis. Strategis mengandung arti bahwa pemuda adalah kader penerus kepemimpinan nasional dan juga lokal (desa), pembaharuan keadaan, pelopor pembangunan, penyemangat bagi kaum remaja dan anak-anak. Karena itu, paling tidak ada 3 peran utama yang bisa dilakukan pemuda sebagai kader penerus bangsa, yaitu; sebagai organizer yang menata dan membantu memenuhi kebutuhan warga desa; sebagai mediamaker yang berfungsi menyampaikan aspirasi, keluhan dan keinginan 
warga; dan sebagai leader, pemimpin di masyarakat, menjadi pengurus publik/warga.

Pemuda adalah generasi penerus bangsa yang di harapkan dapat menjadi pemimpin masa depan, menjadi panutan untuk generasi setelahnya dan menjadi gerigi penggerak berkembangan suatu pedesaaan dalam kategori umur menurut WHO, Pemuda adalah orang-orang yang berkisaran umur 10-24 tahun, WHO menyebut pemuda sebagai young people. Sedangkan menurut international youth year yang diselenggarakan tahun 1985 mendefinisikan penduduk 15 - 24 tahun sebagai kelompok pemuda. konsep diri adalah sesuatu yang menjadi poin penting dalam diri seorang pemuda, pengertian dan harapan seseorang mengenai bagaimana dirinya yang dicita-citakan dan bagaimana dirinya dalam realita yang sesungguhnya, baik secara fisik maupun psikologisnya. (Hurlock dalam catur,2000) membuat para pemuda lebih dapat mengatur kepribadiannya, dalam menentukan arah dan pengembangan terhadap potensinya untuk masa depan desa. Hal tersebut tak dapat dipungkiri bahwa harapan berperan penting dalam konsep diri seseorang. harapan sendiri adalah keseluruhan dari kemampuan yang dimiliki individu untuk menghasilkan jalur mencapai tujuan yang diinginkan, bersamaan dengan motivasi yang dimiliki untuk menggunakan jalur-jalur tersebut. Harapan didasarkan pada harapan positif dalam pencapaian tujuan. (Snyder ,2000).

Harapan mengambil peran penting saat mengalami hambatan dalam hidup. Teori harapan menekankan peran dari hambatan, stressor, dan emosi. Ketika menjumpai hambatan yang menghalangi pencapaian tujuan, individu menilai kondisi tersebut sebagai sumber stres. Berdasarkan postulat teori harapan, emosi positif dihasilkan dari persepsi mengenai keberhasilan pencapaian tujuan. Sebaliknya emosi negatif mencerminkan kegagalan pencapaian tujuan, baik yang mengalami hambatan ataupun tidak mengalami hambatan. Oleh karena itu, persepsi mengenai keberhasilan pencapaian tujuan akan mendorong munculnya emosi positif dan negatif (Snyder \& Sympson, dalam Snyder, 2000). Kemudian emosi ini bertindak sebagai reinforcing feedback. Tercapainya harapan tentunya dilandasi dengan konsep diri yan matang, terbentuknya konsep diri seseorang berasal dari interaksinya dengan orang lain. Konsep diri pada individu bukanlah sesuatu yang dibawa sejak lahir, konsep diri timbul, tumbuh dan berkembang karena dipengaruhi oleh lingkunganya, dipengaruhi oleh interaksi tiap-tiap individu serta pengalaman yang dialaminya.

\section{KERANGKA KERJA TEORITIK}

\section{Konsep diri}

William H.Fitts (1971:138) mengemukakan bahwa konsep diri merupakan aspek penting dalam diri seseorang, karena konsep diri seseorang merupakan kerangka acuan (frame of reference) dalam berinteraksi dengan lingkungan. la menjelaskan konsep diri secara fenomenologis, dan mengatakan bahwa ketika individu mempersiapkan dirinya, beraksi terhadap dirinya, memberikan arti dan penilaian serta membentuk abstraksi tentang dirinya, berarti ia menunjukkan suatu kesadaran diri (sefl awareness) dan kemampuan untuk keluar dari dirinya sendiri untuk melihat dirinya seperti seperti yang ia lakukan terhadap dunia diluar dirinya.

Komponen Konsep Diri

a) Diri Ideal (Self Ideal)

Menentukan sebagian besar arah hidup seseorang. Diri ideal menentu-kan arah perkembangan diri dan pertumbuhan karakter serta kepribadi-an. Diri ideal merupakan gabungan dari semua kualitas dan ciri ke-pribadian orang yang sangat di-kagumi. Diri ideal merupakan gam-baran dari sosok seseorang yang sangat dikagumi.

b) Citra Diri (Self Image)

Citra diri Adalah cara individu melihat diri sendiri dan berpikir mengenai diri individu sekarang/saat ini. Citra diri sering disebut sebagai cermin diri. Individu akan senantiasa melihat kedalam cermin ini untuk mengetahui bagaimana cara individu tersebut harus bertindak atau berlaku pada suatu keadaan tertentu.

c) Harga Diri (Self Esteem)

Harga diri adalah komponen yang bersifat emosional dan merupakan komponen yang paling penting dalam me-nentukan sikap dan kepribadian seseorang. Harga diri merupakan kunci untuk mencapai keberhasilan hidup. Harga diri didefinisikan se-bagai kecenderungan untuk me-mandang diri sendiri sebagai pribadi yang mampu dan memiliki daya upaya dalam menghadapi tantangan-tantangan hidup yang mendasar dan layak untuk hidup bahagia. Harga diri akan menentukan semangat, antusias, dan motivasi diri.

\section{Harapan (hope)}

Harapan merupakan kemampuan diri pada seseorang dalam keadaan sulit sekalipun untuk merencakan jalan keluar dalam upaya mencapai tujuan dan menjadikan motivasi sebagai suatu cara 
untuk mewujudkan. Harapan dapat diungkapkan dengan 4 aspek yakni optimis, rehabilitasi,kemampuan dan penyesuaian. Untuk mengukur harapan dapat digunakan skala AHS (Adult Hope Scale) dari R. Snyder (2000) yang terdiri dari beberapa aitem yang merupakan pengembangan dari keempat aspek dasar harapan.

Faktor- Faktor yang Mempengaruhi Harapan

Weil (2000) dalam penelitiannya mengemukakan bahwa terdapat beberapa faktor yang dapat mempengaruhi harapan, yaitu dukungan sosial, kepercayaan religius, dan kontrol.

\section{a. Dukungan Sosial}

Harapan memiliki kaitan erat dengan dukungan sosial. Dalam penelitiannya mengenai pasien yang menderita penyakit kronis (Raleigh dalam Weil, 2000) mengatakan bahwa keluarga dan teman pada umumnya diidentifikasikan sebagai sumber harapan untuk penderita penyakit kronis dalam beberapa aktivitas seperti mengunjungi suatu tempat, mendengarkan, berbicara dan memberikan bantuan secara fisik.

b. Kepercayaan Religius

Kepercayaan religius dan spiritual telah diidentifikasikan sebagai sumber utama harapan dalam beberapa penelitian. Kepercayaan religius dijelaskan sebagai kepercayaan dan keyakinan seseorang pada hal positif atau menyadarkan individu pada kenyataan bahwa terdapat sesuatu atau tujuan yang telah ditetapkan sebelumnya untuk situasi individu saat ini. Raleigh (dalam Weil, 2000) menyatakan bahwa kegiatan religius merupakan strategi kedua yang paling umum untuk mempertahankan harapan dan juga sebagai sumber dalam mendukung harapan pada pasien dengan penyakit kronis.

c. Kontrol

Mempertahankan kontrol merupakan salah satu bagian dari konsep harapan. Mempertahankan kontrol dapat dilakukan dengan cara tetap mencari informasi, menentukan nasib sendiri, dan kemandirian yang menimbulkan perasaan kuat pada harapan individu. Kemampuan individu akan kontrol juga dipengaruhi selfefficacy (Venning, dkk dalam Weil, 2000) yang dapat meningkatkan persepsi individu terhadap kemampuannya akan kontrol.

d. Komponen Harapan

Komponen harapan dari snyder (1994) terdiri dari 3 komponen, yaitu tujuan (goals)dapat didefinisikan sebagai sesuatu yang menjadi target atau titik akhir dari urutan aktivita mental, daya kehendak (willpower) mengarah pada motivasi yang diperlukan untuk memulai dan mempertahankan langkah menuju tujuan. Daya kehendak merupakan persepsi diri yang dapat digunakan sepanjang jalan untuk menjapai tujuan. Memiliki daya kehendak bermanfat untuk memulai sesuatu dan mempertahankan ketekunan dalam perjalanan mencapai tujuan. Kemudian yang terakhir adalah strategi (waypower) yang merupakan langkah atau jalan menuju tujuan yang diinginkan, diperlukan untuk mencapai tujuan dan mengarahkan individu jika menjumpai halangan.

\section{Hubungan Antara Konsep Diri (Self Concept) Dan Harapan (hope)}

Hario dan Nangimatur (2016) Agar harapan / yang dicita-citakan itu dapat tercapai maka remaja harus memiliki konsep diri yang matang. Konsep diri adalah citra subjectif dari diri dan pecampuran yang kompleks dari perasaan, sikap dan persepsi bawah sadar maupun sadar. Konsep diri memberi kerangka acuan yang mempengaruhi manajemen terhadap situasi dan hubungan dengan orang lain (dalam potter \& perry, 2005). Konsep diri yang baik maka akan membentuk sebuah harapan yang positif, begitupun sebaliknya. Konsep diri adalah gambaran yang dimiliki orang tentang dirinya, yang merupakan gabungan dari keyakinan yang dimiliki orang tentang diri mereka sendiri, seperti karakteristik fisik, psikologis, sosial, emosional, aspirasi, dan prestasi (dalam Hurlock, 1990:58). Dengan adanya konsep diri inilah maka remaja akan mudah untuk mencapai harapannya, sehingga dapat mewujudkan perubahan bangsa nantinya.

\section{METODE}

Dalam penelitian ini peneliti menggunakan metode kuantitatif, karena menggunakan jasa statistika dalam proses analisis datanya. Penelitian kuantitatif adalah penelitian yang banyak menggunakan angkaangka mulai dari pengumpulan data, penafsiran terhadap data serta penampilan dari hasilnya (Arikunto, 2002). Rancangan penelitian yang digunakan dalam penelitian ini adalah rancangan korelasi yaitu suatu penelitian yang bertujuan untuk menemukan ada atau tundaknya suatu hubungan. Dalam penelitian ini peneliti ingin mengetahui seberapa besar hubungan konsep diri pada harapan di kalangan pemuda desa. Dalam penelitian ini peneliti mengambil kurang lebih 30 sampel pemuda 
di masing-masing desa, sehingga ada 90 pemuda yang menjadi sampel penelitian.

Bentuk item kuesioner yang digunakan dalam penelitian ini adalah item kuesioner tertutup dimana pertanyaan yang dicantumkan telah disesuaikan oleh peneliti. Alternatif jawaban yang disediakan bergantung pada pemilihan peneliti sehingga responden hanya bisa memilih jawaban yang mendekati pilihan paling tepat dengan yang dialaminya. Kuesioner penelitian tertutup memiliki prinsip yang efektif jika dilihat dengan sudut pandang peneliti sehingga jawaban responden dapat disesuaikan dengan kebutuhan. Instrumen dalam penelitian ini menggunakan pedoman angket yang disusun berdasarkan skala likert. Pertama angket mengenai konsep diri yang merupakan variabel bebas (X). Dengan skala adolence self-concept short scale (ASCSS) dari Piers-Harris. Kedua, yaitu skala harapan (hope) beck's hopelesness scale yang merupakan variabel terikat $(\mathrm{Y})$ yang sudah diadaptasi oleh peneliti.

\section{HASIL DAN PEMBAHASAN}

Berdasarkan hasil uji statistik teknik korelasi penelitian, diperoleh bahwa hipotesis yang berbunyi“ ada hubungan antara self-concept dan hope pemuda desa ", diterima. Hasil korelasi antara self concept dengan hope menunjukkan bahwa ada hubungan yang positif dan signifikan karena $p$ $<0.05$. dikatakan positif karena hubungan antara kedua variabel tersebut adalah linier atau searah. $\mathrm{Hal}$ ini berarti jika variabel $\mathrm{X}$-nya tinggi maka variabel $Y$-nya juga ikut tinggi, dalam hal ini jika tingkat self-concept pemuda tinggi maka hope pemuda juga akan tinggi.

Metode pengumpulan data yang digunakan dalam penelitian ini menggunakan skala dengan mode likert dengan empat pilihan alternative jawaban yakni Sangat Tidak Setuju (STS), Tidak Setuju (TS), Setuju (S), dan Sangat Setuju (SS). Skala likert digunakan untuk mengukur sikap, pendapat, dan presepsi seseorang atau sekelompok orang tentang fenomena sosial (Sugiono, 2013 dalam Marlinda dkk, 2015).

Hasil uji coba kemudian di uji validitas dan reliabilitasnya. Pengujian validitas merupakan analisis aitem dengan menggunakan rumus koefisien korelasi aitem-total (item-total correlation) dengan bantuan spss version 16.00 for windows. Pengujian reliabilitas dilakukan dengan menggunakan cronbach's alpha dengan bantuan spss version 16.00 for windows. Berdasarkan hasil perhitungan skala self-concept memliki cronbach's alpha 0.912 dengan jumlah 38 item yang tidak gugur, sedangkan skala hope memiliki cronbach's alpha 0.920 dengan jumlah 26 item yang tidak gugur. Menurut Arikunto (2013) dalam Marlinda, dkk (2015), suatu variable dalam instrumen dikatakan reliable jika nilai koefisien cronbach's alpha. 0,6. Berdasarkan hasil analisis dengan menggunakan teknik product moment, diperoleh hasil sebagai berikut:

\begin{tabular}{llll}
\hline & & $\begin{array}{l}\text { Self- } \\
\text { concept }\end{array}$ & Hope \\
\hline \multirow{2}{*}{ Self-concept } & Pearson & 1 &, $715\left(^{* *}\right)$ \\
& \begin{tabular}{lll} 
Correlation \\
\cline { 2 - 3 }
\end{tabular} & Sig. (2-tailed) &, 000 \\
\hline \multirow{2}{*}{ Hope } & $\begin{array}{l}\text { Pearson } \\
\text { Correlation }\end{array}$ &, $715\left(^{* *}\right)$ & 1 \\
\cline { 2 - 4 } & Sig. (2-tailed) &, 000 & \\
\hline
\end{tabular}

Correlation is significant at the 0.01 level (2-tailed).

Dari tabel tersebut dapat disimpulkan bahwa terdapat hubungan antara konsep diri (sefl concept) dengan harapan (hope) pada pemuda desa di kabupaten malang di desa Wajak, Sumawe, dan Dampit. Nilai Koefisien korelasi bertanda positif (+) 0,715 artinya hubungan konsep diri dengan harapan pada pemuda desa di kabupaten malang di desa Wajak, Sumawe, dan Dampit searah, semakin tinggi (positif) konsep diri seseorang maka akan semakin tinggi juga harapan yang akan ia capai, begitupun sebaliknya.

Dua variabel merupakan variabel searah yaitu Naiknya angka pada satu variabel diikuti dengan naiknya angka pada variabel lain dan turunnya angka pada sau variabel diikuti dengan turunnya angka pada variabel lain. Jika ada tanda negative (-) berarti bahwa hubungan yang terjadi antara dua variabel berlawanan arah yaitu naiknya angka pada satu variabel diikuti dengan turunnya angka pada pada variabel lain dan turunnya angka pada satu variabel diikuti engan naiknya angka pada variabel lain (Azwar, 2015).

Berdasarkan hasil analisis dapat diketahui bahwa variabel self-concept memiliki nilai minimum 86.00 nilai maksimum 165.00 , rata-rata 134.00 dan standart deviasi 17,78476 . Sedangkan variabel hope memiliki nilai minimum 86.00 , nilai maksimum 152.00 , rata-rata 112.00 dan standart deviasi 18,0166 . 

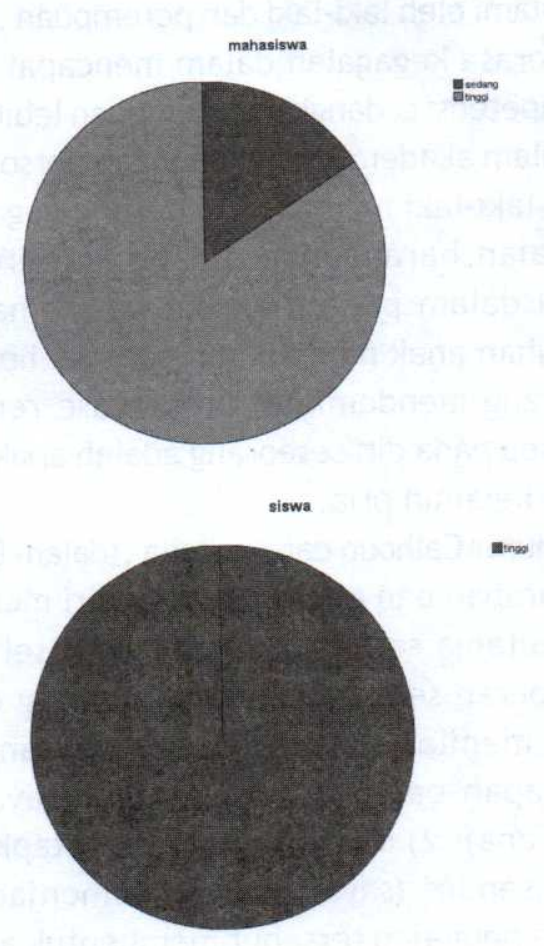

Berdasarkan diagram tersebut dapat diketahui bahwa seluruh subyek 57 pemuda $100 \%$ pemuda memiliki hope tinggi. Dan $15.8 \%$ untuk 9 pemuda memiliki self-concept sedang dan $84.2 \%$ untuk 48 pemuda memiliki self-concept yang tinggi. Penelitian ini di dukung oleh penelitian terdahulu yang dilakukan oleh nangimatur dan hario (2016) mengenai self-concept dan hope pada mahasiswa psikologi 2014 dengan Hasil penelitian menunjukan bahwa adanya hubungan positif antara konsep diri dengan harapan mahasiswa, dengan hasil analisis data koefisien korelasi sebesar 0.562 dan taraf signifikansi 0.000 .

Hasil penelitian di atas sesuai dengan pendapat wiraman bahwa Konsep diri adalah konsep dasar tentang diri sendiri, pikiran dan opini pribadi, kesadaran tentang apa dan siapa dirinya, danbagaimana perbandingan antara dirinya dengan orang lain serta bagaimana beberapa idealisme yang telah dikembangkannya. Konsep diri merupakan aspek diri yang sangat penting karena kepribadian dan konsep diri seseorang akan mempengaruhi seluruh tindakan orang tersebut (Wirawan, 2001, h.16). Konsep diri sangat erat kaitannya dengandiri individu. Kehidupan yang sehat, baik fisik maupun psikologi salah satunya didukung oleh konsep diri yang baik dan stabil.

Oleh sebab itu, konsep diri yang terbentuk pada remaja cenderung tidak konsisten. Masa remaja adalah masa dimana seseorang mencoba me-nyusun puzzle diri sendiri. Kepingan-kepingan puzzle itu antara lain penampilan, kecerdasan, kepribadian, dan keterampilan-keterampilan lain-nya sehingga terbentuk apa yang dinamakan konsep diri. Dari kemampuan remaja menyelesaikan masalah inilah lahir konsep diri orang dewasa yang cenderung menetap (Agustiani, 2004:18). Terbentuknya konsep diri ini akan membentuk citra diri (self image) dan harga diri (self esteem) remaja. Menurut Gunawan (2003:19-23) citra diri adalah cara individu melihat diri sendiri dan berpikir mengenai diri individu sekarang/saat ini, sedangkan harga diri (self esteem) adalah kecen-derungan untuk memandang diri sendiri sebagai pribadi yang mampu dan memiliki daya upaya dalam menghadapi tantangan-tantangan hidup yang mendasar dan layak untuk hidup bahagia. Harga diri akan menentukan semangat, antusias, dan motivasi diri. Menurut Hamachek (dalam Rakhmat, 2001:106) remaja yang memiliki konsep diri positif akan sanggup mengaku kepada orang lain bahwa ia mampu merasakan berbagai dorongan dan keinginan, dari perasaan marah sampai cinta, dari sedih sampai bahagia, dari perasaan kekecewaan yang mendalam sampai kepuasan yang mendalam pula. Jadi dengan memiliki konsep diri positif, maka remaja akan mampu mengenali emosinya dengan baik dan mampu memotivasi dirinya, sehingga dapat diartikan bahwa konsep diri seseorang akan mempengaruhi kecerdasan emosionalnya.

Tabel

\section{Pengkategorisasian Tinggi Rendahnya Hope Dan} Self Concept Individu Berdasarkan Gender

\section{Desa Gunung Sudo}

\begin{tabular}{cccccc}
\hline \multirow{2}{*}{ No } & \multirow{2}{*}{ Kategori } & \multicolumn{2}{l}{ Hope } & \multicolumn{2}{c}{ Self concept } \\
\cline { 2 - 6 } & L & $\mathbf{P}$ & $\mathbf{L}$ & $\mathbf{P}$ \\
\hline 1 & Tinggi & 9 & 12 & 6 & 11 \\
\hline 2 & Rendah & 0 & 0 & 3 & 1 \\
\hline Jumlah & 9 & 12 & 9 & 12 \\
\hline
\end{tabular}

Jumlah anak 22

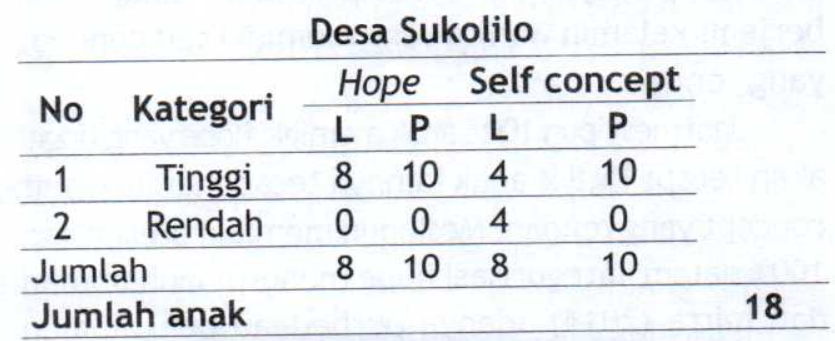


Desa Majang Tengah

\begin{tabular}{cccccc}
\hline \multirow{2}{*}{ No } & \multirow{2}{*}{ Kategori } & \multicolumn{2}{c}{ Hope } & \multicolumn{2}{c}{ Self concept } \\
\cline { 3 - 6 } & & $\mathrm{L}$ & $\mathbf{P}$ & $\mathrm{L}$ & $\mathbf{P}$ \\
\hline 1 & Tinggi & 11 & 7 & 10 & 7 \\
\hline 2 & Rendah & 0 & 0 & 1 & 0 \\
\hline Jumlah & 11 & 7 & 11 & 7
\end{tabular}

Jumlah anak

Dari hasil penelitian diatas ditemukan dari 57 anak dari keseluruhan desa dikateorisasikan bahwa 28 anak berjenis kelamin laki-laki dan 29 anak berjenis kelamin wanita. Dari kategorisasi tinggi rendahnya variabel hope pada 57 anak ini, ditemukan bahwa $100 \%$ memiliki hope yang tinggi, dalam penelitian tidak ditemukan anak yang memiliki hope yang rendah.

Menurut snyder (2000) menyatakan bahwa harapan adalah keadaan yang termotivasi yang positif didasarkan pada hubungan interaktif agency (energy yang mengarah pada tujuan) dan pathway (rencana untuk mencapai tujuan). Harapan yang baik akan menunjang konsep diri yang lebih baik pada individu, menunjukkan konsep diri yang positif pada diri seseorang. Ditekankan lagi oleh teori harapan dalam alex, harapan mencerminkan persepsi individu terkait kapasitas mereka untuk mengkonseptualisasikan tujuan-tujuan secara jelas, mengembangkan strategi spesifik untuk mencapai tujuan tersebut ( pathway thingking), menginisiasi dan mempertahankan motivasi untuk menggunakan strategi tersebut (agency thingking).

Akan tetapi mengenai variable self concept dari 57 anak yang menjadi subjek penelitian dari 3 desa yang telah ditentukan peneliti, dalam disimpulkan bahwa ada 9 anak yang memiliki self concept yang rendah dan 48 lainnya dalam kategorisasi tinggi, hal ini menyebabkan bahwa presentase self concept dari keseluruhan anak yang memiliki self concept yang tinggi hanya $84.2 \%$, yang artinya ada $15,8 \%$ anak yang memiliki self concept yang rendah dan yang mendominasi diantara adalah pria dengan 8 anak yang berjenis kelamin pria dan 1 anak yang berjenis kelamin wanita yang memiliki self concept yang rendah.

Jadi meskipun $100 \%$ anak memiliki hope yang tinggi akan tetapi 15,8\% anak lainnya tetap memiliki self concept yang rendah. Meskipun memiliki presentase $100 \%$ dalam kategorisasi hope menurut Muhammad dan mirra (2014) adanya perbedaan pengalaman yang dialami oleh laki-laki dan perempuan , laki-laki lebih merasa kegagalan dalam mencapai harapan dan kompetensi sedangkan perempuan lebih merasa gagal dalam akademik dan hubungan personal. Jadi seorang laki-laki memang cenderung gagal dalam pencapaian harapannya dibanding perempuan terbukti dalam penelitian bahwa memang dari keseluruhan anak memiliki presentase hope $100 \%$ tetapi yang mendominasi presentase rendahnya self konsep pada diri seseorang adalah anak dengan berjenis kelamin pria.

Menurut Calhoun dan Acocella ,(dalam Desmita, 2012) harapan dan penilaian akan diri merupakan dimensi utama self concept individu, setiap hari kita berperan sebagai penilaian tentang diri kita sendiri, menilai apakah kita bertentangan: 1) pengharapan bagi diri kita sendiri (saya dapat menjadi apa), 2) standar yang kita tetapkan bagi diri kita sendiri (saya seharusnya menjadi apa). Hasil dari penilaian tersebut membentuk apa yang disebut dengan rasa harga diri, yaitu seberapa besar kita menyukai diri sendiri.

Menurut Pudjigjogyanti (1988), ada tiga alasan yang dapat menjelaskan peranan konsep diri dalam menentukan perilaku seseorang salah satunya adalah konsep diri menentukan pengharapan individu. Mc. Candless mengatakan bahwa konsep diri merupakan seperangkat harapan serta penilaian perilaku yang menunjuk kepada harapan-harapan tersebut.

\section{KESIMPULAN}

Dari hasil penelitian yang telah ditemukan dapat ditarik kesimpulan bahwa hope dan self konsep pada pemuda desa memiliki hubungan simetris dimana variable 1 tidak mempengaruhi variable 2 , jadi tinggi rendahnya hope yang dimiliki seorang anak tidak mempengaruhi self konsep bagi beberapa anak. Ditemukan bahwa $15,8 \%$ anak yang memiliki hope yang tinggi tetap memiliki self konsep yang rendah dan yang mendominasi kategori rendah adalah anak pria dengan jumlah kategorisasi rendah adalah 8 anak dan untuk anak yang berjenis kelamin wanita hanya 1 anak yang meskipun memiliki hope yang tinggi tetap memiliki self konsep yang rendah. Menurut Muhammad dan mirra lelaki dibandingkan dengan wanita cenderung gagal dalam pencapaian harapannya itu disebabkan karena perbedaan pengalaman. 


\section{DATAR PUSTAKA}

Abrianto, Hario \& Nangimatur R. Hubungan Self concept Terhadap Hope pada Mahasiswa Psikologi Semester 4 Universitas Islam Negeri (Uin) Maulana Malik Ibrahim Malang.Jurnal, tidak diterbitkan. malang:UIN Maulana Malik Ibrahim.

Agustiani, Hendriati. 2006. Psikologi Perkembangan Pendekatan Eko-logi Kaitannya dengan Konsep Diri dan Penyesuaian Diri Pada Remaja. Jakarta: Refika Adi-tama.

Azwar, Saifuddin. 2015.Tes Prestasi. Yogyakarta: Pustaka Belajar.

Feliciano veiga \& antonio lette.2016. Adolencent self-concept short scale: a version of PHCSCS. Procedia - Social and Behavioral Sciences 631 - 637. Lisbon: Lisbon University -Institute of Education, Lisbon

Hurlock, Elizabeth B. 1980. Psikologi Perkembangan Suatu Pendekat-an Sepanjang Rentang Kehidupan Edisi ke Lima. Jakarta: Erlangga.

Koentjaraningrat. 1994. metode-metode penelitian masyarakat. Jakarta: pt gramedia pustaka utama

Mirra, Muhammad. 2014. Pengalaman Kegagalan Pada Laki-Laki dan Perempuan. Jurnal Psikologi. Vol 10. No 2. Hal 95-102
Nicole Gardner Neblett, Kai Schnabel Cortina. Adolescents' thoughts about parents' jobs and theirimportance for adolescents' future orientation

Shane J Lopes. 2009. The Encyclopedia f possitive psychology. Vol. 1 .Hal.487

Supriatna, Endang .2016. Hubungan Konsep Diri Remaja Dengan Perilakunya Di Desa Tegalpanjang Kecamatan Cireunghas Kabupaten Sukabumi. Skripsi(S1) Thesis, Fisip Unpas. Bandung : universitas pasundan

Sutopo, oki rahardianto dan nanda harda.2014. "Transisi pemuda dalam masyarakat risiko: antara aspirasi, hambatan dan ketidakpastian". Jurnal. vol. 11 no. 3. Jakarta: Universitas paramadina.

Snyder, C.R. (2000). Hypothesis: There is Hope. In C.R. Snyder (Eds.), Handbook of Hope Theory, Measure and Applications (pp.3-21). San Diego: Academic Press.

Snyder, C.R. dan Hal S. Shorey, dkk. (2002). Hope and Academic Succes In College. Jurnal of educational psychology. Vol. 94. No 4. Hal 820-826

Widyaningsih, wiwik .2010. "Analisis harapan dan persepsi kualitas jasa pelayanan kesehatan terhadap kepuasan pasien di instalasi rawat jalan rsud ambarawa". Jurnal. Semarang: Universitas Dian Nuswantoro. 